\title{
Vozes dissonantes das quebradas nos Contos Negreiros, de Marcelino Freire
}

\author{
Luciana Paiva Coronel $^{1}$
}

Assim, a literatura contemporânea não será necessariamente aquela que representa a atualidade, a não ser por uma inadequação, uma estranheza histórica que a faz perceber as zonas marginais e obscuras do presente, que se afastam de sua lógica. Ser contemporâneo, segundo esse raciocínio, é ser capaz de se orientar no escuro e, a partir daí, ter coragem de reconhecer e de se comprometer com um presente com o qual não é possível coincidir.

Karl Erik Schollhammer.

Uma série de vozes emerge dos Contos negreiros, de Marcelino Freire, obra publicada em 2005 e em 2006 contemplada com o Prêmio Jabuti de Literatura. Vozes muito variadas, em boa medida desconhecidas do público leitor em sua razão e textura específica, vozes que compõem a "prosódia corrida que vem lá dos cafundós, lá de nós. Da moral dos banzos que guardam o possível blues da palha da cana" (p.11), conforme Xico Sá apresenta a obra nas páginas iniciais. Tratam-se de vozes cujo resgate ficcional conforma uma imagem estarrecedora do Brasil de nossos tempos, um país em que o convívio social tem a marca do preconceito e do medo que emanam do desconhecimento do outro. Heranças muito arcaicas de nosso processo histórico, construído sob o comando da casa-grande sobre a senzala, cuja fala "negreira" é aqui recuperada, revelando-se como a música “de quem masca o bagaço das pestes, das chagas" (p.12), ainda segundo o prefaciador.

O mérito do conjunto das obras do autor é inquestionável. Surgido na cena literária nacional junto ao grupo inicial das antologias da "Geração 90", ele iniciou sua produção

\footnotetext{
${ }^{1}$ Professora adjunta de literatura brasileira na Universidade Federal do Rio Grande (FURG).
}

Brasiliana - Journal for Brazilian Studies. Vol. 3, n.1 (Jul. 2014). ISSN 2245-4373. 
própria com os livros de contos Angu de sangue, de 2000 e BaléRalé, de 2003. Organizou obras coletivas relacionadas às formas breves, como a "Coleção 5 minutinhos" em 2002 e o livro Os cem menores contos brasileiros do século, em 2004. Suas mais recentes publicações foram o livro de contos RasiF: mar que arrebenta, de 2008, e o romance Nossos ossos de 2013. Esta escrita ficcional, marcada desde o início pela combinação da temática social com o experimentalismo formal (que permitiu ousadias como a fusão do texto com outras linguagens, como as fotografias da obra de estreia), encontra-se em etapa de renovação com a publicação da primeira narrativa longa, o que sugere desdobramentos imprevisíveis na carreira deste pernambucano de 46 anos que optou por residir em São Paulo desde o início dos anos 90.

A produção ficcional de Freire, devido ao amplo repertório de personagens marginais que congrega - desempregados, prostitutas, homossexuais, donas de casa, crianças, trabalhadores braçais, infratores, moradores do lixão - alarga o horizonte de representação da literatura brasileira contemporânea, dando voz a um tipo de personagem que pouco figura nas tramas usuais, de acordo com o mapeamento realizado por Regina Dalcastagné (2012). A própria estudiosa afirma:

Nossas cidades literárias são feitas, na verdade, de ausências: mulheres, pobres, cegos, portadores de deficiências físicas e mentais, velhos, crianças, estão todos de algum modo excluídos das ruas e contornos urbanos que se delineiam nos textos contemporâneos. Neste sentido, temos um pálido retrato da vida fervilhante, desconfortável e violenta de nossas cidades - por onde as mulheres circulam com suas sacolas, suas pastas e seus bebês, (...), por onde os pobres tem de passar, nem que seja só para chegar até o trabalho. (Dalcastagné, 2003, p. 24). 
O que mais chama atenção na polifonia fervilhante dos dezesseis contos, chamados "cantos" a fim de apontar já de início para a raiz de oralidade ali contida, é o humor. A senhora de "Linha de tiro", que não entende a abordagem do assaltante no ônibus, confunde-o sucessivamente com um vendedor de balas e chocolates, um Hare Krishna, um cego, um doente pedindo dinheiro para comprar remédio. Numa estrutura de diálogo que conforma um flash surpreendente do cotidiano violento das grandes cidades, o assaltante já impaciente grita que é um assalto, e no desencontro inelutável das vozes, a senhora indaga por que seu interlocutor não faz alguma coisa, não chama a polícia, provocando no leitor o riso. $\mathrm{Na}$ Babel das ruas de nosso dias, o desentendimento é geral, o que, no conto, termina por proteger a idosa da investida do assaltante.

Também "Nação Zumbi" traz a marca do humor, mas a situação do personagem que vê frustrada sua tentativa de venda de um rim deixa um travo mais amargo no leitor. "Cuidar da minha saúde ninguém cuida" (p.54), protesta ele, ao ver desmoronar o sonho de voar "feito um Orixá" até a África, onde o comércio de órgãos é livre, abraçar outro negrão igual a ele, salvar uma vida e ainda voltar para a casa com muito dinheiro. A polícia, que não se preocupa com os meninos soltos na rua, "tanta criança morta e inteirinha, desperdiçada em tudo que é esquina" (p.55), ele menciona com raiva, vem à sua porta encher de soco o rim que supostamente estaria preservando de se converter em mercadoria. "E o rim, não é meu?", (p.53), indaga, estupefato, diante da proteção recebida à revelia de sua vontade.

Muito mais estupefato fica o leitor diante do questionamento recebido, pois percebe que o diálogo desta vez lhe inclui, conformando uma espécie de desabafo cujo efeito de realidade é incontestável. Possivelmente simpático à proteção fornecida pelo Estado para garantir a integridade física das pessoas, o leitor é colocado em situação de 
perplexidade pela voz do outro, que reivindica o direito de mutilar-se em troca de benefícios financeiros. E ainda acusa a polícia de agir com violência contra si no exercício da tarefa de protegê-lo. Como sair dessa zona de estranhamento completo em que o texto nos deixa? Como julgar o outro? Melhor ouvi-lo e aceitar o desafio de tentar entendê-lo.

É a esta utopia da escuta compreensiva que o canto nos conduz. Diante de uma voz que manifesta a intenção de comercializar parte de seu corpo, que clama pela liberdade de fazer isso, o que pensar? No mínimo, percebemos quão restritas são as oportunidades de acumulação para este personagem, que pode ser tomado sem maiores riscos como representante de parte significativa da população brasileira. E também quão frágil é a nossa democracia, alicerçada em conceitos abstratos de cidadania que não oportunizam a amplos segmentos sociais a possibilidade de viver do próprio trabalho preservando o corpo da cobiça do mercado internacional de órgãos.

Octávio Ianni considera que em nosso país "uma parte importante das lutas e controvérsias sobre a democracia [...] implica a compreensão das heranças de séculos desse regime de trabalho" (1988, p.11), referindo-se ao escravismo. Entende ainda o sociólogo que "muito do que tem sido a sociedade brasileira no século XX ressoa a influência do escravismo." (idem). Seria possível complementar sua avaliação e afirmar que a herança do escravismo mantém-se viva na sociedade brasileira no século XXI, no qual perdura um sistema cultural que ainda determina em termos desfavoráveis as condições de vida do negro.

Citando Roger Bastide, que considerava que "se a escravidão é um crime, a sua supressão, sem a preparação preliminar das massas que vão ser jogadas à liberdade, é provavelmente um crime maior" (p.226), Ianni ressalta a dificuldade da inserção produtiva dos ex-escravos na sociedade de classes em formação, na qual a ideologia 
racial do branco mantinha-se cristalizada, oferecendo a negros e mulatos apenas ocupações braçais pouco valorizadas. O triste quadro social de nossos tempos, que é o foco central dos cantares dissonantes de Contos negreiros, espelha exclusões provenientes do período colonial que apenas muito recentemente começaram a merecer alguma atenção da parte do Estado.

Vão no mesmo sentido de "Nação Zumbi", por manifestarem um outro desconhecido, pelo menos no que toca às nossas conjecturas acerca do que é o outro e do que ele quer, os cantos "Totonha" e "Curso superior". No primeiro, a personagem avisa já na entrada: "Não quero aprender, dispenso" (p.79). Em seguida, expõe suas razões: “Deixa pra gente que é moço. [...] Deixa eu aqui no meu canto. Na boca do fogão é que fico. Tô bem. Já viu fogo ir atrás de sílaba? (p.80). Novamente o leitor é confrontado com uma voz cuja razão parece contrariar um direito fundamental: o acesso à instrução básica, luta histórica das camadas populares em prol da superação de sua subalternidade.

Totonha, deixada à margem do universo escolar até a idade adulta, construiu-se a si e ao seu mundo, a partir de referenciais próprios. A chegada tardia da "dona professora" a coloca em situação de desconforto, por isso sua recusa. E novamente uma indagação é dirigida diretamente aos ouvidos do leitor: “Tem esforço mais esforço do que o meu esforço? Todo dia, há tanto tempo, acordando nesse esquecimento. Acordando com o sol. Tem melhor bê-a-bá? Assoletrar se a chuva vem, se não vem?" (p.80).

Como não aceitar os argumentos de Totonha? Como negar-lhe o direito de rebelarse contra o letramento? Como impor-lhe a cartilha, se ela, privada da escrita, sobreviveu sem saber para que esta lhe serviria? Contrariando concepção arraigada acerca da dimensão libertária da educação, ela entende o aprendizado como submissão a um 
código alheio, por isso opta por preservar a sua autonomia: “Eu é que não vou baixar a minha cabeça para escrever. Ah, não vou." (p.81). O leitor se depara neste final paradoxal com a proclamação do direito à ignorância por parte da protagonista. Como desrespeitá-lo? E como respeitá-lo, se acreditamos que a plena cidadania passa pelo domínio do código escrito? Totonha, assim como o personagem que queria vender seu rim, apresentam ao leitor desejos que são ao mesmo tempo irrecusáveis e inaceitáveis. Embaralham-se as lógicas dessas visões de mundo, a deles e a do leitor, e o que sobra é a certeza da complexidade do real que este conto espelha com rara sensibilidade.

Os Contos negreiros de Marcelino Freire representam, com maestria, feridas sociais que ainda sangram em nosso país, mesmo que seja possível apontar alguns avanços inegáveis neste terreno na conjuntura atual. $\mathrm{O}$ canto "Curso superior" alude possivelmente a um deles, as cotas para o ingresso no ensino superior, cuja implementação recente no Brasil rendeu polêmicas candentes. A elite nacional protestou ao ver a universidade a que tinha acesso privilegiado ser "invadida" por pessoas de variadas cores e de distinta origem. Considerou racista a política pública de inclusão social e não a hostilidade violenta que dirigiu aos novos universitários.

O canto inicia com a voz de um candidato à vaga na universidade vislumbrando a chegada no espaço inteiramente novo. Ao invés da alegria esperada, o personagem manifesta um receio angustiado, oriundo do deslocamento que prevê sentir ao entrar em local pouquíssimo frequentado por pessoas como ele: "O meu medo é entrar na faculdade e tirar zero eu que nunca fui bom de matemática fraco no inglês eu que nunca gostei de química geografia e português o que é que eu faço agora hein mãe não sei ." (p.97)

A voz proveniente "da margem" da sociedade se vê subitamente lançada ao "centro", identificado neste caso, assim como no episódio de "Totonha", com a 
instituição de ensino. Enquanto aquela dispensa o aprendizado formal, sentindo-se já pronta para a vida sem ele, este se sente despreparado para aproveitar a oportunidade que se abre, dirigindo à mãe seu canto ritmado de aflição. Repetem-se como um refrão na abertura de todos os parágrafos as palavras "o meu medo", dotando o discurso de força poética e reiterando a amplitude do medo sentido, que não é apenas de ordem intelectual: “O meu medo é o preconceito e o professor ficar me perguntando o tempo inteiro porque eu não passei porque eu não passei porque eu não passei porque eu fiquei olhando aquela loira gostosa o que é que eu faço se ela me der bola hein mãe não sei." (p.97). Misturam-se em sua mente fragilidades escolares, inquietações afetivas e ainda a certeza da discriminação de que será alvo: o novo lhe apavora.

Enraizado nas bordas da cidade, o protagonista antecipa o sentimento de uma alteridade absoluta na sala de aula do terceiro grau. Mesmo que concluísse o curso, ele se julga amputado de um futuro diferenciado e amarrado a uma tradição inelutável, ser preso, destino estatisticamente previsto de grande parte dos jovens como ele: "O meu medo é que mesmo com diploma debaixo do braço andando por aí desiludido e desempregado o policial me olhe de cara feia e eu acabe fazendo uma burrice sei lá uma besteira será que vou ter direito a uma cela especial, hein mãe, não sei." (p.97). O único benefício pressentido pelo jovem devido ao acesso aos bancos universitários seria um tratamento diferenciado na cadeia, nada mais.

O conto "Curso superior" mais uma vez faz o leitor entender quão arraigadas são as estruturas da exclusão em nosso país. Estruturas que o processo histórico não consegue de imediato reverter porque encontram-se introjetadas, gerando a consciência de inferioridade de que o protagonista é portador. Mesmo diplomado, estando castrado de sonhos e de um repertório mais amplo de expectativas, ele é refém da estreiteza dos 
caminhos que sua mente traçou, vendo-se perdido e desamparado pelas ruas da cidade. Até ser preso, conforme conjectura.

A ameaça da polícia é uma constante nos cantos, seja por serem assaltantes alguns daqueles que falam, seja por serem prostitutas, profissionais altamente vulneráveis às investidas policiais, seja por representarem ficcionalmente uma parcela dos brasileiros que historicamente a polícia não protege, mas persegue: os negros residentes nas periferias urbanas. "Não tem quem goste de polícia" (p.26), diz um personagem de "Solar dos príncipes", conto que, assim como "Curso superior", traz circunstâncias novas da vida nacional. Mostrando que o fosso social que divide o país ainda é imenso, uma vez que as mudanças em curso demandam tempo para sedimentar padrões identitários menos estigmatizados, Marcelino Freire não deixa de representar os papeis até pouco tempo imprevistos que passam a exercer na recente conjuntura os segmentos "negreiros" de nossa população. Entre estes novos perfis está a atividade de produção de filmes.

Tendo mais uma vez o humor como marca central, o canto "Solar dos príncipes" inicia com a voz de um narrador externo à cena, mas bastante próximo da mesma: “Quatro negros e uma negra param na frente deste prédio." (p.23). Em seguida a focalização narrativa assume um movimento muito dinâmico, sendo exercida ora por personagens variados, ora por esta voz externa. Estes deslocamentos constantes constituem um recurso muito eficiente de representação da caótica cena que é narrada no no momento mesmo em que ocorre: cinco moradores do Morro do Pavão tentam entrar em um prédio para filmar a vida da classe média, de modo similar ao que fazem os cineastas que sobem o morro com a intenção de registrar a vida dos favelados.

Revela-se de novo o peso dos preconceitos enquadrando os olhares e as convicções quando do encontro com os diferentes. O inusitado é que no caso do porteiro que acolhe 
os cineastas amadores, trata-se de uma diferença ínfima, pois este é também um homem negro de origem nordestina, como os visitantes. O único diferencial está na inserção social, pois o porteiro está a serviço da manutenção da ordem, e vê como ameaça o bando que se aproxima. Através do discurso indireto livre acompanhamos o seu pensamento: "Filmando? Ladrão é assim quando quer sequestrar. Acompanha o dia a dia, os costumes, a que horas a vítima sai para trabalhar." (p.22).

A explicação de que o grupo queria realizar um longa-metragem não convence, o porteiro, que de novo enxerga apenas o que o seu medo revela: “- 'Metra o quê?' Metralhadora, cano longo, granada, os negros armados até as gengivas." (p.22). E ainda uma vez ele reage de acordo com as ideias da classe média que está encarregado de proteger. Quando a mulher lhe mostra o microfone, tentando convencê-lo da veracidade de sua intenção de filmar, ele vislumbra no mesmo apenas a arma que sua mente prevê na cena: "Vou bem levar paulada de microfone?" (p. 22), indaga-se.

Não há saída, na lógica do porteiro cinco negros tentando entrar em um prédio bem situado só podem estar pretendendo assaltá-lo. Um dos jovens do morro percebe a incoerência de suas atitudes: "Esse porteiro nem parece preto, deixando a gente preso do lado de fora. O morro tá lá aberto 24h. A gente dá as boas-vindas de peito aberto. Os malandrões entram, tocam no nosso passado. A gente se abre que nem passarinho manso. A gente desabafa que nem papagaio. A gente canta, rebola. A gente oferece a nossa coca-cola." (p.25).

Para replicar o gesto da classe mais favorecida, que irrompe no morro para flagrar a intimidade de seus moradores, os jovens começam a rodar o filme ali mesmo, na entrada do prédio e à revelia do porteiro, sem perceber que este, ao apertar os botões, não avisava os moradores do prédio acerca da filmagem, como eles ingenuamente supuseram, mas pedia socorro para o assalto que prefigurava. $\mathrm{O}$ desdobramento 
inevitável do conto é o fracasso do plano inicial e o registro em "câmera violenta" da chegada da polícia, sirenes e muitos tiros: "Assustador. Apareceu gente de todo tipo. E a ideia não era essa. Tivemos que improvisar. Sem problema, tudo bem. Na edição a gente manda cortar." (p.27). Sendo os autores do filme, os jovens do morro editam as cenas a seu modo, e logram o maior dos objetivos pretendidos, fazer cinema pra melhorar o seu cartaz.

Em se tratando da vida "negreira", eivada de dores mestiças e ancestrais, a perspectiva de uma abordagem assim debochada, associada ao desenlace promissor, um final quase feliz, porque os cineastas do morro tem afinal a liberdade de produzir as próprias imagens, não é disseminada no conjunto da obra. E nem poderia ser, porque as falas tratam de misérias e humilhações de todas as ordens. O canto de abertura, “Trabalhadores do Brasil", por exemplo, tematiza os negros em ocupações degradantes. Não por acaso, o tom da narrativa é de revolta:

Enquanto Rainha Quelé limpa fossa de banheiro Sambongo bungo na lama e isso parece que dá grana porque o povo se junta e aplaude Sambongo na merda pulando em cima da ponte tá me ouvindo bem?

Hein, seu branco safado?

Ninguém aqui é escravo de ninguém. (p.19-20)

Causa inquietação imediata no leitor a combinação inusitada de referências da cultura africana, identificadas com a História (Zumbi) e com a religião (Olorum e outros orixás), apresentarem-se no conto associados a atividades pouco ou nada prestigiadas, como aquelas ligadas à limpeza de excrementos referidas na citação acima. A síntese 
estapafúrdia é um grande achado do autor, agregando a grandeza de uma tradição com a degradação de um cenário que não condiz com ela, que a fere e desrespeita. Desse modo, ele representa a riqueza africana desperdiçada, viva, mas pisada e brutalizada, etapa final do processo da diáspora que trouxe ao Brasil os africanos na condição de escravos.

Possivelmente em virtude da consciência de ser portador de uma herança cultural vasta, que pertence aos africanos, a despeito dos serviços rebaixados a que tem sido submetidos desde a chegada à América como mão-de-obra de baixo custo, a voz que entoa o canto dialoga com o leitor desaforadamente, tratando-o como "branco safado" e encerrando todos os parágrafos do texto com a pergunta agressiva "tá me ouvindo bem?" Este que fala conhece a sua força, mas não ignora estar falando de uma posição rebaixada socialmente, por isso seu canto é de desforra: “Enquanto Zumbi trabalha cortando cana na zona da mata pernambucana, Olorô-Quê vende carne de segunda a segunda ninguém aqui com a bunda preta pra cima, tá me ouvindo bem?" (p.19).

Francesco Jordani de Lima considera que “a marginália reunida por Freire em seus cantos desafia e desmistifica o estigma da negritude passiva, pacífica e naturalmente feliz. Apaga da própria imagem o verniz exótico-romântico e a maquiagem da compensação social, a fim de deflagrar a urgência do grito e do gesto detidos." (LIMA, 2008, p.158). A apreciação é de grande valia, pois sintetiza o padrão de representação do negro com o qual a obra de Marcelino Freire rompe, em sintonia com a abordagem explicitamente empenhada dos Estudos Culturais, que entendem a cultura como um campo de luta no qual os sentidos podem ser disputados e as identidades ressignificadas, anunciando, de acordo com Maria Elisa Cevasco (2003), as sementes de uma nova ordem social. 
Revelando personagens que trabalham incansavelmente nas piores ocupações, xingam o leitor na condição de representante da elite branca privilegiada e ociosa, invadem a casa desta, ou pelo menos tentam fazê-lo, para registrar a sua vida, dispensam a sua educação formal e também a sua proteção policial, a obra de Freire aponta para o esgotamento do veio tão fecundo, não apenas na literatura, mas no conjunto das produções culturais nacionais, do malandro simpático e inofensivo.

O canto "Esquece" possivelmente seja um dos que mais se afasta desse padrão de "negritude passiva, pacífica e naturalmente feliz" conforme a definição de Jordani de Lima. Com epígrafe de Marcelo Yuka ("Todo camburão tem um pouco de navio negreiro.") e composto de uma só voz, que trata de definir o que é violência a seu juízo, o canto tem todos os parágrafos, com exceção do último, iniciados por "Violência é...", o que dá ao mesmo tempo ritmo poético e ênfase ao seu discurso. Assim o assaltante inicia o seu canto áspero de afirmação da diferença:

Violência é o carrão parar em cima do pé da gente e fechar a janela de vidro fumê e a gente nem ter tempo de ver a cara do palhaço de gravata para não perder a hora ele olha o tempo perdido no rolex dourado.

$[\ldots]$

Violência é ele ficar assustado porque a gente é negro ou porque a gente chega assim nervoso a ponto de bala cuspindo gritando que ele passe a carteira e passe o relógio enquanto as bocas buzinam desesperadas. (p.31).

No seu ponto de vista, violência é esta que ele sofre no momento em que realiza o assalto, que se desdobra em violência física e simbólica, pois pode ser ferido e também pode perceber que a sua cor negra é motivo de susto antes mesmo que ele mostre ser um 
assaltante. Na sequência do assalto, muito mais violência é prevista caso algo dê errado e os policiais venham acertar as contas diretamente com ele, frustrando qualquer expectativa de felicidade em família:

Violência é acabarem com a nossa esperança de chegar lá no barraco e beijar as crianças e ligar a televisão e ver aquela mesma discussão ladrão que rouba ladrão a aprovação do mínimo ficou para a próxima semana.

\section{$[\ldots]$}

Violência é a gente receber tapa na cara e na bunda quando socam a gente naquela cela imunda cheia de gente e mais gente e mais gente pensando como seria bom ter um carrão do ano e aquele relógio rolex mas isso fica para depois uma outra hora.

Esquece." (p.32-33).

O leitor sabe que há muita violência na história de vida de um jovem infrator, e que esta tem causas profundas, ancoradas em um modelo de sociedade desigual e excludente, mas a inversão do ângulo que define o fenômeno, afastando-se do sujeito que sofre e passando para o sujeito que executa um crime, é realmente um grande achado do conto. Não por acaso, a versão do assaltante sobre o tema, desdobrada em oito parágrafos nos quais a palavra "violência" é martelada com insistência ritmada, é seguida do comentário "isso fica para depois uma outa hora. Esquece", sugerindo a consciência de que os argumentos apresentados serão postos de lado, que as raízes fundas da violência são silenciosas, não importando para a maior parte da sociedade e da mídia que the informa. 
Interessa para a maioria apenas a manifestação mais impactante da mesma, sua eclosão nas ruas em prejuízo da classe média, o que pede como resposta maciça repressão policial. O título do conto, sugestivamente, é “Esquece”, mais uma astúcia do autor, que acentua o esquecimento a que todo o discurso ali contido está fadado, e não o tipo de violência definido em seu interior, a violência sofrida pelo assaltante, aqui representando a imensa massa dos subalternos de cor negra cuja trajetória de vida passa pelos centros de reabilitação de menores e pelos presídios. Como uma espécie de "deixa pra lá", o título do conto aponta para sua própria inviabilidade no tecido social, que inclui a nós leitores, cujo sono e cuja paz exigem certa desatenção acerca do que há por trás da violência que nos atinge, a outra violência, que massacra cotidianamente aqueles que relutamos a considerar cidadãos.

João Cézar de Castro Rocha (2004) considera que um conjunto significativo de obras da cultura brasileira contemporânea manifesta o fenômeno da "passagem da dialética da malandragem à dialética da marginalidade", que consistiria em uma mudança radical nas formas de representar o país. No lugar da antiga possibilidade de conciliação das diferenças - presente em obras que traziam o malandro como imagem preferencial do homem pobre e excluído -, surge a partir dos anos 90, sobretudo em obras como Cidade de Deus (1997), de Paulo Lins, e Capão pecado (2000), de Ferréz, uma crítica certeira da desigualdade social promovida por meio da nova forma de representação do sujeito pauperizado, o bandido violento e ameaçador. Junto a estes autores, na vanguarda do processo, estariam grupos musicais como os Racionais $M C^{\prime}$, cujas canções antecipavam a ruptura que se consolidaria a seguir.

A dialética da marginalidade, conforme Castro Rocha, tem como alvo dramas sociais coletivos e caracteriza-se por um empenho rigoroso de interpretação dos mecanismos de exclusão social, realizado ineditamente pelos próprios excluídos. Os 
Contos negreiros identificam-se com esta tendência geral de radicalização do discurso, aspecto que é ressaltado pelo crítico Karl Erik Schollhammer, quando este afirma: “Freire procura as vozes sem voz, os murmúrios marginais que não se transformam em linguagem, reprimidos, mas também rudes e vingativos que se entranham nas ruas, no chão queimado do Nordeste e nos infernos vários do Brasil." (2009, p.68).

Ainda que seu autor não possa ser considerado um excluído social, a forma de representação dos contos/cantos que compõem a obra, em sua indefinição essencial entre as formas da cultura letrada, altamente prestigiada, e a tradição da oralidade, invariavelmente associada, segundo Paul Thompson (1998), à construção de uma memória mais democrática do passado, revela exatamente o movimento de Freire, autor inserido no sistema literário hegemônico, em direção aos recursos orais da cultura africana. Impregnando a fala direta dos personagens, tais recursos permitem a identificação do texto com os segmentos espoliados ali representados e criam um magnífico efeito de realidade devido à ausência da mediação de um narrador externo compondo sua forma final.

Paulo Roberto Tonani do Patrocínio entende de forma similar as construções de forma narrativa e linguagem de Contos Negreiros: "A utilização do discurso direto visa a alcançar o objeto, busca representar este Outro a partir de seu próprio referencial. O processo de construção discursiva de Freire almeja produzir uma fala que objetiva compreender as situações narradas a partir da lógica do sujeito representado." (2007, p. 197).

O quase desaparecimento da entidade narrativa como eixo estruturador da prosa ficcional de Freire pode ser um resultado desta busca do autor por incorporar organicamente em seu texto a alteridade de que trata, fundindo-a como elemento interno de seu discurso literário. Neste processo de natureza ética e estética de 
delegação de voz ao Outro, com exceção de "Solar dos príncipes", todos os demais textos são apenas ínfimas lascas de narração em meio às vozes dos personagens, que “compõem o hino seco e desalentado dos 'esfarrapados do mundo' 2." (Jordani, 2008, p.164), entoado como um lamento que é lançado diretamente aos ouvidos e à consciência do leitor, agenciando os seus sentidos e a sua razão.

Pode-se identificar nas formas híbridas dos cantos/contos, conformados com recursos mesclados de prosa e poesia, o traço da presentificação, de que fala Beatriz Resende (2007), que o considera marca central da produção literária contemporânea, caracterizada pelo imediatismo e pela urgência de intervir sobre a realidade caótica do presente. Pode-se entender que Marcelino usa a palavra como uma arma de empoderamento de seus personagens esfarrapados ao permitir que falem.

Paulo Tonani reconhece o empenho formal do autor na criação desta voz da alteridade: “Em Contos Negreiros presenciamos [...] o exercício de experimentação literária que visa [...] a criação de um novo vínculo entre estes sujeitos marginalizados, território e linguagem. Nesse sentido, forma-se um discurso que quer ser coletivo, utilizando para tanto um espaço do qual esses grupos sempre foram excluídos: a literatura." (2007, p.201). Na obra em foco, Marcelino Freire abre as portas para que as vozes marginalizadas invadam a página literária e ocupem-na com a urgência de seu sofrimento.

A estudiosa do fenômeno pós-colonial Gayatry Spivak, ao analisar as perspectivas políticas dos sujeitos subalternos em nossa sociedade contemporânea, afirma categoricamente que "nenhum ato de resistência pode ocorrer em nome do subalterno sem que esse ato esteja imbricado no discurso hegemônico". (2010, p.13). A impossibilidade de se articular um discurso que esteja fora da lógica dos discursos

2 Assim o pedagogo pernambucano Paulo Freire denominava os socialmente oprimidos.

Brasiliana - Journal for Brazilian Studies. Vol. 3, n.1 (Jul. 2014). ISSN 2245-4373. 
identificados com o status quo faz com que a pesquisadora indiana não considere a hipótese de que o subalterno tenha sua voz ecoada na sociedade : “O subalterno não pode falar." (p.126).

$\mathrm{Na}$ ficção deste jovem autor pernambucano em geral, e nos Contos negreiros em particular, o subalterno fala. Sua voz, devido ao esforço já apontado do autor na abertura de um espaço discursivo no terreno ficcional, ecoa uma lógica própria, na maior parte das vezes avessa e alheia ao discurso hegemônico, como nos casos citados de Totonha, do vendedor de rim, da prostituta, entre outros. Talvez a única adesão à visão de mundo triunfante na vida social nacional seja realizada pela menina do canto "Nossa rainha”, cuja voz ressoa um desejo construído pelos meios de comunicação de massa: “Mãe, eu quero ser Xuxa. Eu quero ser Xuxa. Eu quero ser Xuxa." (p. 73). Ainda assim, a mãe, sem descuidar da filha, contesta não o desejo desta, mas as circunstâncias sociais que o produziram: "Um dia esfolo essa condenada. Deus me perdoe. Essa danada da Xuxa. [...] Fazer isso com filha de pobre. Que horror! “ (p.74).

Em se tratando de sexualidade, Marcelino rompe com a representação fetichizada do negro como objeto sexual, e de seu corpo como um atrativo que desperta irresistível atração, pois nestes contos o negro deseja tanto quanto é desejado, sofre e plasma em canto suas frustrações amorosas. Incluem-se na pauta "negreira" "bichas" dilaceradas, como a personagem do conto "Coração", outras menos espalhafatosas, como a de "Meus amigos coloridos" e também a de "Meu negro de estimação". Tematizando com especial atenção o desejo homossexual masculino, que se volta ao corpo do homem negro, representado como rebolante e lascivo, os contos vão na contramão do estereótipo usual, que tem no corpo da mulher negra o prato principal do banquete que é servido em larga escala aos machos convencionais do país em episódios como o carnaval, por exemplo. 
Do mesmo modo o conto "Vanicléia", narrado por uma ex-prostituta, desorganiza os padrões de moral e conduta usuais porque em seu discurso a mulher afirma sua diferença em relação ao imaginário que identifica o casamento como a suprema felicidade feminina: ao invés de contentamento, mais uma vez em estrutura de diálogo franco com o leitor, ela lamenta a vida de maus tratos que teve desde que saiu da zona de prostituição para viver uma relação estável com um homem só:

O que é que ele me dá? Bolacha na desmancha. Porradela na canela. Eu era mais feliz antes. Quando o avião estrangeiro chegava e a gente rodava no aeroporto. Na boca quente da praia. Pelo menos, um príncipe me encantava. Naquele feitiço de sonho. De ir conhecer outro lugar, se encher de ouro. Comprar aliança. U, hum. (p. 41)

Ainda que a lembrança de Vanicléia, colega morta depois de ser abusada por policiais, surja em sua mente, ela não reluta em mostrar-se saudosa dos tempos arriscados de meretriz em que a vida ainda podia mudar. Nesses cantos dissonantes das quebradas, mesmo a prostituta, objeto por definição do desejo alheio, tem voz e consciência próprias. E se ela lembra o passado com saudades, não é devido a qualquer espécie de idealização romântica daquele. É somente porque a vida a dois debaixo de um teto do presente mostra-se ainda mais brutal e infeliz do lhe parecia a vida no tempo em que percorria as ruas atrás de clientes estrangeiros.

Os clientes estrangeiros, cabe referir, são um tema importante destes cantos. Invariavelmente identificados com o turismo sexual, eles revelam-se machos bem pouco respeitáveis no trato com as mulheres nos cantos em que comparecem. Pode-se dizer 
complementarmente que não fica melhor representado o homem brasileiro aí presente. No conto recém discutido, ele é um alcoólatra que bate na mulher e vive aludindo ao seu passado de "de piranha e de vagabunda" (p.42). O contraponto não engrandece qualquer das partes.

A voz que fala no canto "Vanicléia" lembra-se de ter sido advertida pelos policiais que a estupravam de que "devia respeitar o homem brasileiro" (p.42), possivelmente pelo fato de que vendia seu corpo a estrangeiros. A situação poderia ser considerada cômica, se não fosse trágica, estupradores exigindo o respeito daquela a quem violentavam... Do ponto de vista da mulher, os brasileiros saem perdendo na comparação: “Homem? U-hum. Não vale um tostão pelas bandas daqui. Os caras [estrangeiros] pelo menos tinham educação, outra finura..." (p.42).

Não é isso que se vê nos cantos "Alemães vão à guerra" e "Yamami", que trazem as vozes dos turistas estrangeiros relatando viagens de conquistas, verdadeiras " caças", que envolvem mulheres cuja condição negreira independe da cor da pele, sendo constitutiva da subalternidade da sua condição. O primeiro traz um alemão em diálogo com um conterrâneo, no qual vangloria-se dos benefícios do seu dinheiro na vida das negras das regiões por onde passa: "Nosso dinheirro salvarria, porr exemplo, as negrrinhas do Haiti. Barratas como as negras do Burundi. Trouxe uma parra aqui, lembrra?" (p.37).

Junto ao dinheiro dado, o alemão gaba-se pelo amparo "civilizacional" fornecido, num discurso eivado de traços típicos da mentalidade europeia do período colonial: "A gente acaba dando educação a esse povo, Johann. E um pouco de esperança. E herrança. [...] O que serria dela sem mim?" (p.37). Sem mencionar jamais a contrapartida recebida no negócio, ele tenta convencer o amigo a fugir do frio, acompanhando-o rumo a 
Salvador: "O que não falta nesse mundo, Johann, é amorr." (p.38), diz o mesmo com sarcasmo.

Atrás de amor é que supõe viajar este tipo de turista, cuja representação Marcelino realiza com mordacidade, aproximando sua busca de uma guerra, conforme o título do conto. Nesta guerra, o alvo a ser abatido são as negras de todas as partes do mundo: “Nem sei se tem negrras na Conchinchina. Johann, alô. Alô, Johann. Se tiverr, eu vou." (p.38). Oferecendo ao leitor a voz que reproduz em tempos de economia globalizada a sujeição da camada negreira, desdobrando-a em novos papeis e identidades subalternizadas, no caso relacionados com o sexo, o autor completa o quadro da vida social contemporânea: não haveria novos espaços de senzala, se a casa grande não se renovasse em nossos dias.

"Yamami" vai bem mais longe na representação do turismo estrangeiro predatório por envolver uma criança índia do Brasil como o fetiche sexual motivador da viagem. Novamente é o próprio homem, de nacionalidade desconhecida, que fala: “Sempre gostei de crianças. Aqui é proibido. Yamami, meu tesouro perdido." (p. 105). Ele relata que chegando ao Norte do Brasil, facilmente se encontram "putas" de onze anos ou menos, "seminuas, sujinhas e deliciosas", de "pele vermelha e ardente" (p.106), mas sua lembrança é uma só: “O cheiro caçador de Yamami, os seus peitinhos. Pequenininhos. Seus olhos flechando os meus testículos. [...]. Minha alegria primitiva, Yamami. O meu sorriso."(p.108).

A representação contundente do livre acesso de um homem pedófilo ao corpo de uma índia ainda impúbere deixa o leitor em estado de revolta. A crueza da descrição do ato sexual precocemente conduzido, porque a menina é toda "pequenininha" está além do suportável para o leitor comum: “a "mão fininha de Yamami vai e vindo" (p.107). Tem mérito o autor pela execução impecável desta voz cujo relato bate como uma 
chibata em nossa consciência. Até mesmo porque, além de uma patologia individual, o canto apresenta liberalidades institucionais, cuja existência acaba por permitir este tipo de atitude criminosa em nosso país: “Lá posso colocar Yamami no colo e ninguém me enche o saco. E ninguém fica me policiando. Governo me recriminando." (p.108).

Assim termina o conto e com ele o livro, arruinando o sossego do leitor, que neste momento encerra uma leitura capaz de deixar-lhe as cicatrizes indeléveis de que fala Júlio Cortázar ao definir o efeito de um bom conto no leitor. Marcelino Freire criou nestes cantos/contos um universo de lamentos negreiros doloridos e vigorosos, ricos como forma de expressão contundente de chagas sociais muito antigas. Para reconhecêlo como herdeiro de uma linhagem muito particular, o próprio autor nos apresenta a série onde inscreve a si e à sua produção. Ela comparece quase ao final da edição, trazendo nomes de poetas e ficcionistas da literatura brasileira identificados com a temática no negro: Castro Alves, Cruz e Souza, Ferréz, Lima Barreto e Jorge de Lima. Qual será a continuidade desta estirpe? Que outros autores, na esteira de Marcelino, darão atenção aos clamores negreiros? A questão está em aberto. Só podemos esperar que haja no futuro menos razões para uma escrita dilacerada como a dos Contos negreiros. Mas esta não é uma questão que pertença ao âmbito literário e sim ao movimento sempre atrasado das mudanças sociais em nosso país.

\section{Referências Bibliográficas}

Cevasco, Maria Elisa. Dez lições sobre estudos culturais. São Paulo: Boitempo, 2003.

Dalcastagné, Regina. Sombras da cidade. Revista Ipotesi n.7, v.2. Juiz de Fora, 2003. 
. Literatura brasileira: um território contestado. Vinhedo: Editora Horizonte, Rio de Janeiro: Ed. UERJ, 2012. Um mapa de ausências, p.147-196.

Dealtry, Giovanna, Lemos, Masé, Chiarelli, Stefania (org). Alguma prosa: ensaios sobre literatura brasileira contemporânea. Rio de Janeiro: 7 Letras, 2007.

Patrocínio, Paulo Roberto Tonani do. Contos negreiros: a escrita como forma de aproximação do outro, p.193-202.

Freire, Marcelino. Contos negreiros. 7.ed. Rio de Janeiro/São Paulo: Record. 2013.

Ianni, Octávio. As metamorfoses do escravo. 2.ed. SP: Hucitec/ Curitiba:Scientia e Labor, 1988.

Lima, Francesco Jordani Rodrigues de. Cantos e cantares em Contos negreiros, de Marcelino Freire. Revista Via Atlântica, n.12. São Paulo, Faculdade de Filosofia, Letras e Ciências Humanas - USP, dez/2007, p.157-166. Disponível em http://www.revistas.usp.br/viaatlantica/issue/view/4191

Resende, Beatriz. Questões da ficção brasileira do século XXI. Grumo 6.2. dez/2007.

Rocha, João Cezar de Castro. Dialética da marginalidade: caracterização da cultura brasileira contemporânea. Folha de São Paulo. São Paulo, 29 fev.2004. Folha Mais!

Schollhamer, Erik. Ficção brasileira contemporânea. Rio de Janeiro: Civilização Brasileira, 2009.

Spivak, Gayatri Chakravorty. Pode o subalterno falar? Tradução de Sandra Regina Goulart Almeida, Marcos Pereira Feitosa, André Pereira Feitosa. Belo Horizonte: Ed. UFMG, 2010. 
Thompson, Paul. A voz do passado: história oral. Tradução de Lólio Lourenço de Oliveira. 2.ed. Rio de Janeiro: Paz e Terra, 1998. 